\title{
Research on the Cultivation of Teachers' Informatization Ability in Higher Vocational Colleges
}

\author{
Lin Chen \\ Chengdu Agricultural College \\ Chengdu, 611130, China
}

\begin{abstract}
The development of educational informatization from 1.0 to 2.0 stage has raised higher requirements on the informatization ability of teachers in higher vocational colleges. This work first clarified the composition structure of teachers' informatization ability, then evaluated the informatization teaching ability of teachers in higher vocational colleges in Sichuan based on a questionnaire survey. Subsequently, this work analyzed the causes and main problems that lead to the great gap between teachers' informatization professional level and national requirements, and finally proposed operational solutions. Also, this work stressed the cultivation of teachers' informatization teaching ability should be carried out from the aspects of teaching design ability, informatization teaching skills and the expansion of intelligent teaching vision.
\end{abstract}

Keywords-Educational Informatization 2.0; Informatization Ability; Artificial Intelligence; Big Data

\section{INTRODUCTION}

According to global influence, technical feasibility, development potential, and other standards, Artificial Intelligence (AI), Augmented Reality (AR), Blockchain, Unmanned Aerial Vehicle, Internet of Things, Robot, Virtual Reality (VR) and 3D printing will become the intelligent core technology with the most business impact and business value in the next 3-5 years. The Action Plan of Education Informatization 2.0 document issued by the Ministry of Education proposes that "Intelligent environment has changed the way of education and deeply influenced the concept, culture and ecology of education", emphasizes "developing intelligent education and taking the initiative to deal with the new opportunities and challenges brought by the wave of new technology" [1]. Based on emerging technologies such as Artificial Intelligence, big data, and Blockchain, education faces model reform and ecological reconstruction.

In the educational informatization 1.0 stage, teachers in colleges and universities focus on the development of informatization technology literacy in terms of ability training, and comprehensively update from the aspects of teaching consciousness, teaching thinking, teaching role, teaching methods, and informatization technology level improvement. Exploring, verifying and adjusting informatization teaching method, designing flexible informatization teaching

Fund Project: Key Research Base of Philosophy and Social Sciences in Sichuan Province-Center for Teacher Education Research in Sichuan Province: Research on evaluation, existing problems and improvement strategies of informatization teaching ability of teachers in Sichuan vocational colleges from the perspective of "Internet + education" (TER2018-019). Moderator: Lin Chen. classrooms, building or using informatization platform that meets the needs of teaching requirements, teaching rules, and teachers and students' habits, and adopting an objective and accurate informatization evaluation model can present efficient and interesting teaching process and accurate teaching evaluation.

In the educational informatization 2.0 stage, informatization technology will play a supporting and leading role in the education system, and Internet technology will become the cornerstone of future educational development. Teachers in colleges and universities should become the creators of personalized and informational teaching resources, the analysts of big data teaching, and the inclusive of multidimensional ideas, the pursuers of intelligent teaching, and the innovators of learning society. Teachers in colleges and universities who have been influenced by traditional teaching thinking for many years will face unprecedented opportunities and challenges.

\section{CONNOTATION AND REQUIREMENTS OF TEACHERS' INFORMATIZATION ABILITY}

The composition of teacher's informatization ability should include the following five abilities [2]:

First, the ability of acquiring, processing and integrating information. Technically, teachers should have the basic informatization operation ability to complete informatization retrieval, collection and organization; intellectually, they should have the ability of processing and expressing information; consciously, they should have a good sense of information ethics and information consciousness.

Second, the ability of using informatization technology to complete the organic integration, migration and renewal of subject knowledge. Teachers need to have the ability of solving subject problems and practical problems through informatization processing, and innovating teaching design through informatization.

Third, the ability of developing, designing, and reconstructing informatization for the course. Teachers need to optimize courses, develop informatization courses, and constantly adjust and improve courses in the teaching practice process. 
Fourth, teachers should have the ability of using the informatization technology to scientifically organize, monitor the whole process and evaluate multidimensional intelligence.

Fifth, the ability of researching and innovating informatization theory. Through multiple cycles of theory guiding practice and practice innovating theory, the level of informatization theory and practical creation can be improved.

In the new era, informatization teaching puts forward higher ideological requirements in educating people, which means that teachers need to organically integrate cultural education, curriculum ideology and profession ideology [3]. Informatization design should focus on the two-way interaction between teaching and learning, adhere to the students, and pay attention to the cultivation of craftsman spirit. Informatization teaching is not only a technology to improve teaching level, but also an important revolution to return to the teaching center and enhance the teaching realm.

\section{Current Situation OF College Teachers' INFORMATIZATION ABILITY BASED ON QUESTIONNAIRE SURVEY}

The Action Plan of Education Informatization 2.0 urges educational management departments of colleges and universities to play a good role as a baton, launches all teachers to carry out the reform of teaching informatization, and requires all course informatization platforms to migrate, independently develop informatization resources, and formulate assessment standards for informatization application levels. However, teachers in colleges and universities still have doubts about the importance of informatization and concerns about the effectiveness of curriculum informatization reform, so their levels of informatization are uneven, and the application is in response to many problems such as teaching assessment. A questionnaire survey is conducted among vocational colleges in Sichuan province, involving agriculture, forestry, animal husbandry and fishery, electronic information, civil engineering, economic management and basic teaching, and respondents are aged from 20 to 50. The research is mainly carried out from the use of informatization assistance, the mastery degree of informatization technology, and the demand degree of informatization technology.

A. The questionnaire is conducted to investigate the informatization ability of teachers in colleges and universities

\section{1) Informatization technology usage}

According to the survey, $64.52 \%$ of teachers have used informatization technology to assist the teaching in the teaching process, $58.06 \%$ of teachers believes that it is very important to master the informatization technology in the professional development of teachers, and 54.84\% of teachers have significantly improved their teaching effect after using informatization technology. It can be seen that most teachers have fully realized the importance of informatization technology in the teaching process and applied it to the classroom, improving the teaching quality to some extent.

TABLE I. INFORMATIZATION TECHNOLOGY USAGE OF TEACHES

Do you think it is important to master the application of information technology in teaching in teachers' professional development?

\begin{tabular}{|l|c|c|}
\hline option & Subtotal & Proportion \\
\hline A. It's not important. & 3 & \\
\hline B. Not very important & 0 & \\
\hline C. More important & 10 & \\
\hline D. Very important & 18 & \\
\hline Effective filling-in of this question & 31 & $58 \%$ \\
\hline
\end{tabular}

How effective are you in using these techniques?

\begin{tabular}{|l|c|c|}
\hline \multicolumn{1}{|c|}{ Option } & Subtotal & Proportion \\
\hline A. Somewhat lower & 1 & $3.23 \%$ \\
\hline B. No effect & 1 & $3.23 \%$ \\
\hline C. Slightly raise & 12 & $38.71 \%$ \\
\hline D. Marked improvement & 17 & \\
\hline Effective filling-in of this question & 31 & \\
\hline
\end{tabular}


communication software to produce courseware. However, only $19.35 \%$ of teachers are proficient in producing teaching resources through graphics processing software, animation production software, audio processing software, and video production software.

\section{2) Informatization mastery}

In the aspect of mastering informatization technology, teachers are generally skilled in using computer operating systems, and can use the network to search and download teaching resources. They can use office software and real-time

TABLE II. INFORMATIZATION TECHNOLOGY MASTERY OF TEACHERS

Can you be proficient in graphics processing software, animation production software, audio processing software, video production software, etc. to help you make classroom resources?

\begin{tabular}{|l|c|c|}
\hline \multicolumn{1}{|c|}{ option } & Subtotal & Proportion \\
\hline A. Be unfamiliar with & 3 & $9.68 \%$ \\
\hline B. Simple understanding & 9 & \\
\hline C. Basic use & 13 & \\
\hline D. Proficient at mastering & 6 & \\
\hline Effective filling-in of this question & 31 & \\
\hline
\end{tabular}

3) Demand degree of informatization technology improvement

93.55\% of teachers are willing to carry out training in informatization teaching. The top three training intentions include the training of informatization instructional design ability, such as the concept of integrating informatization technology with curriculum integration (93.55\%), skills

training, the construction of informatization teaching resources and the application training (83.87\%), informatization basic knowledge training and skills training, such as courseware production or web page production skills training $(77.42 \%)$. Less than $20 \%$ of teachers identify the application of artificial intelligence, cloud computing, big data and other technologies in teaching.

TABLE III. TEACHERS' DEMAND DEGREE OF INFORMATIZATION TECHNOLOGY IMPROVEMENT

In your opinion, what aspects should teachers' educational technology ability training start from?(Multiple choices)

\begin{tabular}{|c|c|c|}
\hline option & Subtotal & Proportion \\
\hline A. Training of Modern Educational Ideas & 24 & $77.42 \%$ \\
\hline $\begin{array}{l}\text { B. Training of Teachers' Educational and Scientific Research } \\
\text { Ability }\end{array}$ & 17 & $54.84 \%$ \\
\hline $\begin{array}{l}\text { C. Construction and Application Training of } \\
\text { Information-based Teaching Resources }\end{array}$ & 26 & $83.87 \%$ \\
\hline $\begin{array}{l}\text { D. Training in basic knowledge and skills of information } \\
\text { technology, such as courseware or web page production }\end{array}$ & 24 & $77.42 \%$ \\
\hline $\begin{array}{l}\text { E. Training full-time IT teachers on new technologies and } \\
\text { knowledge }\end{array}$ & 23 & $74.19 \%$ \\
\hline $\begin{array}{l}\text { F. The training of information-based instructional design } \\
\text { ability, such as the training of the concept and skills of the } \\
\text { integration of information technology and Curriculum }\end{array}$ & 29 & $93.55 \%$ \\
\hline G. Others & 5 & $16.13 \%$ \\
\hline Effective filling-in of this question & 31 & \\
\hline
\end{tabular}

\section{B. Situation analysis}

From the results of the survey, informatization literacy and informatization thought in teachers need to be improved, and there are still significant differences with the requirements of China. The main problems and methods are mainly:
1) Insufficient level of informatization application

There is a big gap among the stages of basic informatization ability, informatization integration and intelligent teaching. In recent years, the Teaching Ability Competition (started in 2018) and the Informatization Teaching Ability Competition (2012-2017) sponsored by the Ministry of Education have played a leading role in popularizing and 
upgrading the informatization teaching level. Provincial education departments actively organize the competition, which promotes teaching and training, as a result, a group of teachers stands out. Educational function departments of each school successively issue management plans and requirements, requiring teachers to use the informatization teaching platform to carry out teaching resource construction, teaching process supervision, teaching situation feedback and teaching effect inspection, and encouraging teachers to independently develop informatization means suitable for personalized teaching. Teachers are also motivated to open the lecture on informatization application under the vision of intelligent education, and gradually promote the depth and breadth of informatization teaching.

\section{2) Informatization literacy is uneven}

The survey results show that teachers with science and engineering background have better informatization acceptance, and other professional teachers need to further improve their skills. The top priority is to update the concept of teachers through training, so as to clarify the necessity and importance of informatization and integration teaching, reverse rigid ideas with scientific theories, and comprehensively improve the understanding of educational informatization. Then it is necessary to strengthen informatization training, enhance practical operations, and be familiar with educational informatization technology through learning typical informatization teaching cases and the cycle of watching, learning and doing. In terms of new teachers, it is necessary to incorporate informatization training into vocational training, and cultivate the informatization ability before teaching.

\section{Cultivation Strategies OF IMPROVING TEACHER'S INFORMATIZATION ABILITY}

\section{A. Cultivating instructional design ability of informatization teaching}

Adopting informatization technology to integrate instructional design is not only a form change, but also a reconstruction of curriculum analysis, learning analysis, teaching focus, difficult and pain points based on the guidance of new teaching thinking, the improvement of teaching environment, the in-depth analysis of teaching objects, and the accumulation of long-term teaching experience. Using informatization technology can solve various problems that traditional teaching cannot solve well, for example, students growing up under the background of the information age are faced with the problem of shifting their interest and focus, investigation of learning difficulties, full mastery of learning before class, objective analysis of teaching situation in class, feedback of classroom teaching effect, mastery of learning situation after class, course assessment and so on.

The improvement of instructional design ability is not a one-off event, and it requires repeated learning and practice. First of all, teachers should listen to expert lectures to learn theoretical knowledge, and reflect in their majors, courses and classrooms. They should also think about the rationality of teaching content, the effectiveness of teaching organizations, and the feedback on teaching effectiveness. In addition, on the basis of design, they should carry out practice of informatization instructional design and use informatization teaching platforms such as Cloud Classroom, Rain Classroom, Ketangpai, Chaoxing Digital Library or online self-built online teaching platforms, to complete the informatization design practice. Finally, they should analyze the actual situation of classroom teaching through big data collection, find the classroom promotion point, and sublimate the teaching reform. Through repeated design and practice, the informatization design ability will be improved.

\section{B. Cultivating informatization teaching skill}

In terms of conditional variables, both colleges and teachers need to have a shared vision of deepening teaching innovation. The teaching function department should take the lead in informatization training, such as holding expert forums, technical lectures, practical training, skill competitions, informatization teaching conditions, technical assistance and administrative support and informatization teaching assessment programs, so as to perfect incentive mechanisms. Teachers should form a learning atmosphere with all participation and common promotion, and they should use the informatization technology to carry out teaching reform, actively participate in the competition, and achieve a virtuous circle of promoting research with teaching, promoting reform with research and promoting teaching with reform.

Taking the method of cultivating teachers' educational big data thought as an example, teachers need to collect and record the whole process of teaching through informatization, conduct comprehensive analysis and evaluation based on big data evidence chain, analyze the characteristics, advantages and disadvantages of classroom teaching, and compare objective changes of teaching effect before and after the teaching reform [4]. Teachers need to learn about the use of educational big data through training, and then learn how to analyze the data through the course of practical operation.

\section{Cultivating informatization literacy from the perspective of intelligent teaching}

Teachers can teach students in accordance with their aptitude more effectively and create personalized teaching programs if they master the application of "education + $\mathrm{AI}$ ", then they can use artificial intelligence to differentiate teaching The application of artificial intelligence in education mainly includes [5]:

(1) Behavior detection-for example, detecting students' state of learning in the classroom and cheating monitoring in the exam through facial recognition.

(2) Predictive Model-analyzing student's learning big data, predicting whether students can complete the learning requirements, and helping teachers complete the academic situation.

(3) Learning model-such as adaptive learning systems, which pushes personalized learning resources based on student learning behaviors, learning situations, and learning interests.

(4) Intelligent assessment-evaluating and diagnosing learning situations through an adaptive learning system.

Intelligent teaching needs to develop gradually in exploration and research. The formation of literacy is not achieved overnight. The most important thing at present is to 


\section{REFERENCES}

broaden the horizon, understand the development trend of technology, contact and accept new ways of thinking and technology, and further master and apply it to teaching practice, so as to bring about teaching innovation through technological innovation.

\section{SUMMARY}

While improving the ability of informatization teaching, teachers are accompanied by the growth of professional ability and the improvement of professional skills. The improvement of informatization teaching level is not only the improvement of technical level, but also the clear definition of talent training standards, the understanding of the curriculum system, the control of the courses they teach, the mastery of the academic sentiment, and the accurate design of each lesson. Informatization technology acts as a means to support the overall improvement of the teaching level. Teachers in colleges and universities need to meet the reform requirements of the times with an open mind and actively face the arrival of the educational 2.0 informatization age [6].
[1] Ministry of Education of the People's Republic of China. Notice of the Ministry of Education on Printing and Distributing the Action Plan of Educational Informatization 2.0[EB/OL].

http://www.moe.gov.cn/srcsite/A16/s3342/201804/t20180425_334188 . html,2018-04-18.

[2] Xing Wang. Research on the Cultivation of Teachers' Informatization Teaching Ability[J]. Journal of Anhui Vocational College of Electronic and information technology, 2015, 14(6)

[3] Yu Xiangdong. Research on the Organic Combination of Ideological and Political Courses and Curriculum Ideology Based on the Fundamental Tasks of Strengthening Moral Education and Cultivating Characters[N]. Guangming Daily, 2019-03-27(06).

[4] Y100 Education. Teachers should be Equipped with Big Data Thinking Methods and Means in the Age of Informatization[EB/OL]. http://baijiahao.baidu.com/s?id=1606770021230803762\&wfr=spider\&f or=pc, 2018-07-23.

[5] China Education Equipment Purchasing. Application and Research Status of Artificial Intelligence in the Field of Educational Evaluation[EB/OL]. https://www.caigou.com.cn/news/2018070285.shtml, 2018-7-2.

[6] Qiao Jianyong. Reform of Education and Teaching in Colleges and Universities in the Informatization Age[J]. China Higher Education, 2016(Z2): 61-63. 